Geo-Marine Letters

L.J. Poppe - D.S. Foster - W.W. Danforth

U.S. Geological Survey, 384 Woods Hole Road, Woods Hole, MA 02543, USA

\title{
Character and Distribution of Exposed Glaciodeltaic Deposits off Outer Cape Cod, Massachusetts, and Their Effects on Hydrogeology and Benthic Habitats
}

\begin{abstract}
Sea-bed outcrops of glaciodeltaic sediments were identified in four places east of Cape Cod, Massachusetts during seismic-reflection, multibeam bathymetric and backscatter, bottom photographic, and sediment sampling surveys. These strata record coarser-grained ice-proximal glaciofluvial topset to finer-grained distal glaciolacustrine bottomset deposition within deltaic systems that prograded southwestward into glacial lakes from the South Channel lobe about $18 \mathrm{ka}$ B.P. These beds are important because they (1) influence the outer Cape's hydrogeologic framework, and (2) provide relatively stable, locally rough habitats within an area of seafloor dominated by mobile sand and gravelly sediment, and benefit the benthic fauna by providing shelter and a substrate amenable to burrow construction.
\end{abstract}

\section{Introduction}

The ecosystem of outer Cape Cod, Massachusetts, is being stressed by rapid population growth, commercial and recreational fishing, and coastal erosion. Evaluating the environmental effects of these stresses requires information on nearshore geologic framework, processes, and habitats. For example, increased residential development results in contaminants being returned to the Cape's freshwater aquifer through on-site septic systems. In response, towns shift from dispersed, smallcapacity domestic wells to larger, more centralized municipal supplies. However, this shift to large-capacity municipal wells may result in unacceptable declines in water table elevations, decreases in groundwater discharges to streams and coastal areas, and saltwater intrusion of coastal aquifers (Masterson 2004). Information on nearshore framework geology improves our understanding of the outer Cape's hydrogeology and will facilitate the development, calibration, and application of future groundwater flow models necessary to manage this resource.

This paper describes the distribution, character, and facies of glaciodeltaic sediments exposed on the seafloor east of Cape Cod, relates these outcrops to the Quaternary stratigraphy of outer Cape Cod, and discusses their hydrologic and ecologic importance.

\section{Geological setting}

Outer Cape Cod is a product of glacial processes during the late Pleistocene and storm and tidally dominated marine processes during the Holocene sea-level rise. The late Wisconsinan Laurentide ice sheet reached its maximum extent and southernmost position about $20 \mathrm{ka}$ B.P., as marked by terminal moraines on Martha's Vineyard and Nantucket and the southernmost limit of abundant gravel on the adjacent seafloor (Schlee and Pratt 1970; Oldale 1992; Uchupi et al. 1996; Fig. 1a). A lobate ice front was formed by the Buzzards Bay lobe that deposited the moraine along the western part of Martha's Vineyard, the Cape Cod Bay lobe that deposited the moraines across eastern Martha's Vineyard and Nantucket, and the South Channel lobe that extended east toward Georges Bank (Oldale and Barlow 1986; Oldale 1992). Shortly prior to $18 \mathrm{ka}$ B.P., the ice front had retreated. The Cape Cod Bay lobe occupied a position along the northern edge of Cape Cod, and 
the Great South Channel lobe lay just north of Great South Channel (Larson 1982; Uchupi et al. 1996; Fig. 1a). About this time, the main part of Cape Cod was deposited as the Barnstable outwash plain, a delta that prograded into the glacial lake that occupied Nantucket Sound dammed by the earlier end moraines. The rate of retreat of the leading edges of the three lobes varied. Deposits associated with the Buzzards Bay lobe are oldest; deposits associated with the Great South Channel lobe are youngest (Oldale and O'Hara 1984; Oldale 1992). Soon after 18 ka B.P., continued retreat of the ice fronts positioned the Cape Cod Bay lobe in the center of Cape Cod Bay, and the Great South Channel lobe northward and eastward of present-day Cape Cod, with an intervening low (Uchupi et al. 1996; Fig. 1b).

As the Cape Cod Bay lobe margin continued to retreat, meltwaters dammed to the south by Cape Cod and to the east by the Great South Channel lobe formed proglacial Lake Cape Cod Bay (Larson 1982; Oldale 1992). Sediments transported by meltwater streams flowing westward and southwestward into this lake from the South Channel lobe created three large deltas that, in order of age, constitute the Wellfleet, Truro, and Eastham outwash plains (Oldale 1992; Fig. 1b). Coarsergrained deposits within these deltas record higher-energy proximal environments and probably represent topset beds; finer-grained deposits within these deltas record lower energy distal environments and probably represent bottomset beds.

The Holocene marine transgression conspicuously modified the outer Cape. Prior to $6 \mathrm{ka}$ B.P., Georges Bank was still exposed, and it partially blocked long-period waves from the east and southeast, but not from the northeast, resulting in net transport toward the south of sediment eroded from the east side of Cape Cod (Zeigler et al. 1964; 1965). After Georges Bank was finally submerged about 6 ka B.P., waves were no longer blocked, northward sediment transport became more pronounced, and the construction of the Provincetown Hook began (Zeigler et al. 1965; Uchupi et al. 1996). During the Holocene transgression, much of the deltaic sediment that constitutes the outer Cape was eroded. Uchupi et al. (1996) estimated that the original eastwardfacing scarp was up to $7 \mathrm{~km}$ farther east than the present shoreline. Outwash deposits remaining on the outer Cape, which presumably overlie crystalline Paleozoic rocks layered with basal till, are 125-150 m thick (Oldale 1969).

Present-day littoral drift along the outer Cape diverges near Nauset. Sediment to the north of Nauset is transported along the coast toward the Provincetown Hook; sediment to the south is transported toward Monomoy Island (Oldale 1992). Construction of the Provincetown Hook and Monomoy Island, and erosion of outwash plains exposed to the Atlantic Ocean continues today. The east-facing bluffs formed by the outwash plains are retreating at rates greater than $2 \mathrm{~m} / \mathrm{year}$ (Oldale 1992).

\section{Materials and methods}

The multibeam bathymetric and backscatter data collected as part of this study were acquired during transits between Provincetown and a mapping project in the Great South Channel (Valentine et al. 2003) during November 1998 aboard the Canadian Hydrographic Service vessel Frederick $G$. Creed (Fig. 1a). The survey, which covers approximately $153 \mathrm{~km}^{2}$ in a narrow band of seafloor that extends from around the northern tip of Cape Cod southeastward to off Monomoy Island, was conducted using a hull-mounted 95-kHz Simrad EM 1000 multibeam echo sounder. This system utilizes 60 electronically aimed beams spaced at intervals of $2.5^{\circ}$ that can ensonify a swath of seafloor up to 7.5 times the water depth. Horizontal resolution, or the footprint of an individual beam on the seafloor, is approximately $10 \%$ of the water depth; vertical resolution approximately 
$1 \%$ of the water depth or better. Thus for the range of water depths within the survey area, $20-50$ $\mathrm{m}$, the horizontal resolution is $1.3-5.0 \mathrm{~m}$ and the vertical resolution is $0.2-0.5 \mathrm{~m}$.

Most processing of the multibeam data was performed at sea. Artifacts and false soundings were removed and the data were adjusted for tidal variations to mean lower low water, gridded, and projected into Mercator. Imagery of the digital terrain models derived from the mulitbeam observations shows seafloor topography in shaded relief (vertical exaggeration of 4 times; illumination from $45^{\circ}$ above the horizon and from an azimuth of $350^{\circ}$ ) and backscatter intensity (a measure of seafloor texture and roughness) at a spatial resolution of $4 \mathrm{~m} /$ pixel. Chirp highresolution seismic-reflection data of nearshore areas along both sides of the outer Cape were also collected as part of this project (Foster and Poppe 2003). All navigation was by differential GPS.

To validate the acoustic data, surficial sediments and/or bottom photography were collected at 89 stations during May-June 2004 aboard the research vessel Rafael, using a modified Van Veen grab sampler equipped with still- and video-camera systems. The photographic data were used to appraise intra-station bottom variability, faunal communities, and sedimentary structures indicative of geological and biological processes, and to observe boulder fields where samples could not be collected. Pre-existing surficial sediment data (Poppe et al. 2003) were used to supplement the new sediment data.

Sediment descriptions are based on the nomenclature proposed by Wentworth (1922) and the size classifications proposed by Shepard (1954). The interpretations of sea-floor features, surficial sediment distributions, and sedimentary environments are based on data from the sediment sampling and bottom photography stations and on imagery derived from the multibeam backscatter intensity and bathymetry.

\section{Results}

\section{Holocene sediments}

The acoustic, sampling, and photographic data show that much of the seafloor along the Atlantic side of the outer Cape is relatively flat (Fig. 2), and that surficial sediments are predominantly noncohesive coarse sand and gravelly sediment reworked from underlying glacial drift. Low $(<10 \mathrm{~cm}$ in height), broad (about $0.5 \mathrm{~m}$ in wavelength) ripples are nearly ubiquitous. Gravel and brownish organic debris are concentrated in the troughs of these ripples (Fig. 3a); sand dollars congregate on the sandier crests. Smaller current ripples are occasionally superimposed on the low broad ripples. Gravelly patches on the seafloor are common, and are littered with cobbles and small boulders, interspaced with patches of finer gravel and rippled sand. Sessile organisms, where present, are densely attached only to larger $(>50 \mathrm{~cm})$ boulders, indicating that, at least during storm events, the coarse sand and gravelly sediments are mobile, implying that sedimentary environments within these areas are characterized by coarse bedload transport.

Larger bedforms are also locally present. Sand waves are found off the northern tip of the outer Cape, and northeast of Monomoy Island in the southern part of the study area. The largest sand-wave field off the northern tip of the Cape is over $5 \mathrm{~km}$ across, and contains waves that exceed $7 \mathrm{~m}$ in height having wavelengths that average over $100 \mathrm{~m}$. Wave crests strike generally perpendicular to the shoreline, but deflect about $45^{\circ}$ westward $1 \mathrm{~km}$ offshore. Sand-wave asymmetry, crest strike, and the presence of megaripples on the sand waves indicate that net transport is westward-southwestward into Cape Cod Bay, and that it is active. Other, smaller sandwave fields off the northern tip of the outer Cape have a similar orientation and asymmetry as the 
largest field, and have crests that are predominantly sand with troughs characterized by gravelly sediments and harder acoustic returns.

The sand waves northeast of Monomoy Island exceed $4 \mathrm{~m}$ in height, trend roughly northeast, and typically have higher backscatter and coarser sediments on their southeast-facing stoss slopes. Although these sand waves are roughly symmetrical, sandy areas on and near the waves are current rippled, suggesting active transport. In general, however, sediments within this area coarsen southward, gravel and gravelly sediment pave much of the bottom, and sandy areas, where present, are thin, as evidenced by patches and individual grains of gravel poking through the surficial sand.

A field of linear scour depressions is centered about $1.7 \mathrm{~km}$ off the northern tip of the outer Cape (near $42^{\circ} 5.6^{\prime} \mathrm{N}, 70^{\circ} 9.5^{\prime} \mathrm{W}$ ). These depressions, the largest of which exceeds $230 \mathrm{~m}$ in length and $35 \mathrm{~m}$ in width, are oriented roughly perpendicular to the shoreline and are floored by coarser sediments, as evidenced by higher backscatter intensity. Although located somewhat far offshore, these features are closely associated with, and apparently at least partly owe their existence to a shallow long-shore sand body. Whether these linear scour depressions indicate a net offshore cross-shelf sediment transport component (Ferrini 2004), or represent large wave-generated ripples associated with the westward along-shore transport off the northern tip of the Cape (Murray and Thieler 2004) is uncertain.

Southwestward from the northern tip of the Cape toward the more protected seafloor within Cape Cod Bay, sedimentary environments characterized by coarse bedload transport progressively give way to lower-energy environments characterized by sorting and reworking, and eventually deposition. Commensurately, surficial sediments in this area progressively fine southwestward from gravelly sediment and sand to silty sand and clayey silt.

\section{Glaciodeltaic deposits}

Exposed glaciodeltaic deposits were identified at four locations on the seafloor east of Cape Cod in water depths varying in the range from $20-30 \mathrm{~m}$. We interpret these deposits to represent various ice-proximal to ice-distal facies that record deposition during construction of the Eastham, Truro, Wellfleet, and Barnstable outwash plains (Fig. 1).

\section{Eastham Plain deposits}

Three facies of the youngest delta, which prograded into glacial Lake Cape Cod Bay and built the Eastham outwash plain, are exposed off the outer Cape (Fig. 1b). At the eastern extent of these outcrops, a large area of bouldery gravel interspaced with small patches of gravelly sediment and coarse sand records ice-proximal glaciofluvial topset deposition (Fig. 2a). Most of the finer sands and gravels that were originally present have been winnowed from the surface in the modern high-energy sedimentary environments characterized by erosion and non-deposition, leaving a bouldery lag deposit (Fig. 3b). The extensive attached biota on these boulders indicates that they are not mobile, even during high-energy storm events. Examples of sessile organisms observed on the boulders in the bottom photography include hydrozoans, sponges, anemones, and seaweed.

A band of tabular blocks that rise over $1 \mathrm{~m}$ above the surrounding seafloor and can exceed $400 \mathrm{~m}$ across are concentrated along the southern edge of the bouldery area (Fig. 2a). These slabs become smaller and more widely spaced both westward and northward. Although the surface of these blocks is characterized by fine, moderately well sorted sand and an undulating appearance 
(Fig. 3c), preservation of these blocks indicates that denser, more cohesive sediments (i.e., muddy sand and sandy mud) probably compose the interiors. Based on sediment grain size and relatively low backscatter intensity, we interpret these blocks to be the remnants of foreset beds from the delta that produced the Eastham outwash plain (Smith and Ashley 1985). As the sandy ice-distal topset beds were eroded by the Holocene current regime, the foreset beds over which they had prograded were exposed. The cohesive, muddier sands of these foreset beds were more resistant, and part of this facies is preserved as erosional outliers. Abundant skate observed on the tabular blocks suggest that they are an important habitat for these fish (Fig. 3c).

A small exposure of light bluish gray mud (observed at $41^{\circ} 54.6^{\prime} \mathrm{N}, 69^{\circ} 56.6^{\prime} \mathrm{W}$ ) is interpreted as an outcrop of glaciolacustrine sediment that was deposited in the distal part of the delta that built Eastham outwash plain. Although limited within our multibeam coverage, larger exposures of these fine-grained sediments are exposed just shoreward to the west. High-resolution seismic-reflection data reveal that this unit is present on the Atlantic side of the Cape off South Wellfleet and North Eastham, and on the Cape Cod Bay side off North Eastham (Foster and Poppe 2003), and showed a seismic facies characterized by closely spaced (rhythmic) internal reflectors within glacial drift (Fig. 4). East-west seismic lines on the Atlantic side show that this unit dips landward and that it is truncated to the east by the Holocene transgression and exposed on the seafloor. Poor subbottom penetration and discontinuous-to-chaotic reflectors in these records represent sandy and gravelly unstratified drift deposited under more ice-proximal, higher energy glaciofluvial conditions, probably as deltaic topset beds. Good $(>20 \mathrm{~m})$ acoustic penetration and resolution of internal reflectors suggest muddy sediments deposited under more distal, lower energy glaciolacustrine conditions, probably as bottomset beds in this delta.

Bottom photography and sediment sampling show these beds to be light bluish gray, cohesive, semi-consolidated, and variably composed of silty clay and clayey silt with smaller amounts of very fine sand (Fig. 3d). Outcrop relief exceeds $1 \mathrm{~m}$. Degradation of the outcrops, as evidenced by talus piles beneath ledges and abundant slabs and rip-up clasts on the surrounding seafloor, presumably occurs during high-energy storm conditions and appears to be primarily along weak planes or varves, giving the outcrops and talus a blocky angular appearance. Bioerosion, although probably not as important a mechanism of degradation, is ongoing. For example, lobsters use the muddy cohesive outcrops to construct burrows (Fig. 3e).

\section{Truro Plain deposits}

Narrow, somewhat discontinuous exposures of gray semi-consolidated silty clay (centered near $42^{\circ} 5^{\prime} \mathrm{N}, 70^{\circ} 6.5^{\prime} \mathrm{W}$ ) are interpreted to be outcrops of glaciolacustrine sediments of the Truro outwash plain (Fig. 2b). These sediments were distally deposited as bottomset beds of the delta that prograded into glacial Lake Cape Cod Bay slightly less than $18 \mathrm{ka} \mathrm{B.P.,} \mathrm{but} \mathrm{before}$ construction of the Eastham Plain delta (Oldale 1992; Fig. 1b). Multibeam data show that this deposit rises about $1 \mathrm{~m}$ above the surrounding seafloor, has abnormally steep sides and abrupt edges, and, as such, it probably constitutes an erosional outlier. Bottom photography shows that the flat areas on top of the beds are partially covered by a thin veneer of rippled sand and that outcrops at the edges of these outliers have a rough honeycombed appearance (Fig. 3f). Although this rough appearance may be partially due to variations in grain size or induration, it is probably due to bioerosion.

Wellfleet Plain deposits 
An elongate patch of bouldery gravel interspaced with small patches of gravelly sediment and coarse sand (centered near $42^{\circ} \mathrm{N}, 69^{\circ} 58^{\prime} \mathrm{W}$ ) probably records more ice-proximal glaciofluvial topset deposition within the delta that produced the Wellfleet outwash plain (Figs. 1b, 2c). As with the topset beds of the younger Eastham Plain described above, the Wellfleet topset sediments have been winnowed, leaving a gravelly lag deposit. Fish use the bottom roughness for shelter, and sessile forms populate the boulders.

\section{Barnstable Plain deposits}

Another set of narrow, somewhat discontinuous outcrops off Chatham (centered near $41^{\circ} 41.4^{\prime} \mathrm{N}, 69^{\circ} 48.9^{\prime} \mathrm{W}$ ) are also interpreted to be exposures of glaciolacustrine sediments (Fig. $2 \mathrm{~d}$ ). Although these outcrops have not been verified with bottom photography or sampling, based on their morphology and lower backscatter intensity relative to the surrounding seafloor, we interpret them to be composed of fine-grained glaciolacustrine sediments. Similar to the other distal bottomset sediments off Truro (Fig. 2b), the outcrops off Chatham have abnormally steep sides and abrupt edges. Surficial sediments on the surrounding seafloor are dominated by coarse noncohesive sands and gravels that have gradational boundaries, and will not support such steep slopes.

The southerly location of the glaciolacustrine outcrops off Chatham suggests that they are older than the Truro and Eastham outwash plains, and may record deltaic sedimentation prograding from the South Channel lobe into glacial Lake Nantucket Sound just prior to $18 \mathrm{ka} \mathrm{B.P.} \mathrm{(Fig.} \mathrm{1a).}$ If this is the case, then these sediments were probably deposited as part of the eastern edge of the Barnstable outwash plain.

\section{Discussion and conclusions}

Although exposed glaciodeltaic deposits constitute only a small portion of the seafloor east of Cape Cod, Massachusetts, they are important for both hydrological and ecological reasons.

Hydrologically, the impermeable distal glaciolacustrine units within the coarser-grained unstratified drift can form aquicludes. Because these units can divide the aquifer they may affect the position of the saltwater/freshwater interface in well fields on Cape Cod, and limit recharge. In turn, this stratigraphy can 1) promote saltwater intrusion and down-coning of the water table surface around wells drilled to above the fine-grained units, 2) up-coning of saltwater in wells drilled to below these units, and 3) poor flow rates in wells drilled into the glaciolacustrine sediments (Fig. 5). This paper demonstrates how our multibeam data, sediment samples, and bottom photographs are used

to identify and characterize exposed glaciodeltaic deposits, and how our seismic profiles are used to trace the glaciolacustrine deposits shoreward where they can be correlated with units in previously described onshore boreholes (Gerhard and Phillips 1989; Masterson 2004). Evidence from our data, together with the information from onshore wells, show that these glaciolacustrine deposits are present from place to place within all of the outwash plains on the outer Cape. Information on their distribution and extent will help constrain future flow-cell models, improve our understanding of the outer Cape's aquifer system, and facilitate better regional ground water management.

Ecologically, exposures of glaciodeltaic strata provide benthic habitats of rough bottom and harder substrate in an area of the shelf dominated by mobile sand and fine-grained gravel. Bottom photography shows that lobsters construct burrows in outcrops of both the winnowed bouldery 
glaciofluvial topset deposits and muddy cohesive ice-distal glaciolacustrine bottomset deposits (Fig $3 \mathrm{~b}$, e). Similarly, finfish shelter under the ledges, overhangs, and boulders; sessile fauna and flora attach themselves to the hard substrate provided by boulders. Most importantly, the data demonstrate that exposed glaciofluvial and glaciolacustrine deposits add considerably to the overall benthic topographic and compositional complexity off the outer Cape. Because many organisms display affinities for certain bottom types and sediment textures, this topographic and compositional complexity affects the distribution and dynamics of the faunal populations and characteristics of the benthic communities by providing a greater variety of seafloor habitats than the relatively flat surrounding seafloor.

\section{Acknowledgements}

We thank the Woods Hole Science Center's Seafloor Mapping Group for assisting with the multibeam processing, and Dann Blackwood for the bottom photography. This work was supported by the Coastal and Marine Geology Program of the U.S. Geological Survey. This manuscript has benefited from critical reviews by Walter Barnhardt, Page Valentine, and Jim Robb (all USGS).

\section{References}

Ferrini VL (2004) Rippled scour depressions - insights from multibeam sonar data. Geol Soc Am Abstr Programs 36:137

Foster DS, Poppe LJ (2003) High-resolution seismic-reflection surveys in the nearshore of outer Cape Cod, Massachusetts. US Geological Survey Open-File Rep 03-235

Gerhard LW, Phillips JD (1989) New drill cores in crystalline bedrock on southeastern Cape Cod, Massachusetts. Geol Soc Am Abstr Programs 21:28

Larson GJ (1982) Nonsynchronous retreat of ice lobes from southeastern Massachusetts. In: Larson GJ, Stone BD (eds) Late Wisconsinan glaciation of New England. Kendall/Hunt, Dubuque, Iowa, pp 101-114

Murray AB, Thieler RE (2004) A new hypothesis and exploratory model for the formation of largescale inner-shelf sediment sorting and "rippled scour depressions". Cont Shelf Res 24:295-315

Masterson JP (2004) Simulated interaction between freshwater and saltwater and effects of groundwater pumping and sea-level change, Lower Cape Cod aquifer system, Massachusetts. US Geological Survey Scientific Investigations Report 2004-5014

Oldale RN (1969) Seismic investigations on Cape Cod, Martha's Vineyard, and Nantucket and a topographic map of the basement surface from Cape Cod to the islands. U.S. Geological Survey Prof Pap 475-D, pp D118-122

Oldale RN, O'Hara CJ (1984) Glaciotectonic origin of the Massachusetts coastal end moraines and 
a fluctuating late Wisconsinan ice margin. Geol Soc Am Bull 95:61-74

Oldale RN, Barlow RA (1986) Geologic map of Cape Cod and the islands. US Geological Survey Miscellaneous Investigations Ser Map I-1763, scale 1:100,000

Oldale RN (1992) Cape Cod and the Islands, the Geologic Story. Parnassus Imprints, East Orleans, Massachusetts

Poppe LJ, Paskevich VF, Williams SJ, Hastings ME, Kelley JT, Belknap DF, Ward LG, FitzGerald DM, Larsen PF (2003) Surficial sediment data from the Gulf of Maine, Georges Bank, and vicinity: a GIS compilation. US Geological Survey Open-File Rep 03-001, CD-ROM

Schlee JC, Pratt RM (1970) Atlantic continental shelf and slope of the United States-Gravels of the northeastern part. US Geological Survey Prof Pap 529-H

Shepard FP (1954) Nomenclature based on sand-silt-clay ratios. J Sediment Petrol 24:151-158

Smith ND, Ashley GM (1985) Proglacial lacustrine environment. In: Ashley GM, Shaw J, Smith ND (eds) Glacial Sedimentary Environments. Tulsa, Oklahoma, Society of Economic Mineralogists and Paleontologists Short Course 16

Uchupi E, Giese GS, Aubrey DG, Kim DJ (1996) The Late Quaternary construction of Cape Cod, Massachusetts - a reconsideration of the W.M. Davis model. Geological Society of America Special Pap 309

Valentine PC, Middleton TJ, Malczyk JT (2003) Sun-illuminated sea-floor topography of Quadrangle 1 in the Great South Channel, western Georges Bank. US Geological Survey Geologic Investigations Ser Map I-2698-B, scale 1:25,000

Wentworth CK (1922) A scale of grade and class terms for clastic sediments. J Geol 30:377-392

Zeigler JM, Tuttle SD, Tasha HJ, Giese GS (1964) Pleistocene geology of outer Cape Cod, Massachusetts. Geol Soc Am Bull 75:705-714

Zeigler JM, Tuttle SD, Tasha HJ, Giese GS (1965) The age and development of the Provincelands Hook, outer Cape Cod, Massachusetts. Limnology and Oceanography, Redfield Volume, pp R298R311

\section{Figure Captions}

Fig. 1a-b Position and chronology of glaciodeltaic sedimentation on outer Cape Cod (Oldale and Barlow 1986; Oldale, 1992). a Shortly prior to $18 \mathrm{ka}$ B.P. the Barnstable outwash plain prograded into glacial Lake Nantucket Sound. Black polygon shows extent of multibeam coverage. b Shortly after 18 ka B.P. the Wellfleet, Truro, and Eastham outwash plains were sequentially prograded into glacial Lake Cape Cod Bay. Also shown are the location of the terminal moraine and subsequent positions of the retreating ice sheet. Locations of exposed glaciodeltaic strata are 
discussed in the text and are shown here by rectangles: 1 - Barnstable, 2 - Wellfleet, 3 - Truro, and 4 - Eastham

Fig. 2a-d Shaded-relief seafloor topography showing glaciodeltaic deposits exposed around outer Cape Cod. a Winnowed ice-proximal topset deposits and erosional outliers of foreset deposits of the Eastham outwash plain. b Fine-grained bottomset deposits of the Truro outwash plain. $\mathbf{c}$ Winnowed ice-proximal topset deposits of the Wellfleet outwash plain. d Fine-grained bottomset deposits of the Barnstable outwash plain. Sand-wave fields, relatively flat nature of most of the surrounding seafloor, and the locations of the bottom photographs in Fig. $3 \mathrm{~b}$, c, and $\mathrm{f}$ are also shown; locations of multibeam imagery are indicated in Fig. 1

Fig. 3a-f Bottom photographs of glaciolacustrine outcrops off outer Cape Cod. a Rippled seabed from near $41^{\circ} 46.6^{\prime} \mathrm{N}, 69^{\circ} 53.4^{\prime} \mathrm{W}$, but characteristic of much of the seafloor off the eastern Cape. Note sand dollars on ripple crest and gravel, shell debris, and dark organics in the trough. b Winnowed topset deposits of the Eastham plain. Note lobster beneath boulder. $\mathbf{c}$ Fine-grained sand and undulating appearance atop foreset deposits of the Eastham plain. d Fine-grained distal deposits of the Eastham plain. Note angularity of degradation. e Video frame showing bioerosion. Note lobster burrow. e Fine-grained distal deposits of the Truro plain. Locations of most photographs are shown in Figs. 2 and 4

Fig. 4 Chirp subbottom profile (modified from Foster and Poppe 2003) showing a seismic facies characterized by closely-spaced internal reflectors that intersects the seafloor. This facies, which we interpret to be glaciolacustrine deposits (Qdl), lies within undifferentiated glacial drift (Qd). The location of bottom photographs in Fig. $3 \mathrm{~d}$ and $\mathrm{e}$ is also shown

Fig. 5 Schematic drawing showing how fine-grained impermeable glaciolacustrine units can affect positions of the fresh/saltwater interface in well fields on Cape Cod (modified from Masterson 2004). These sediments can limit recharge, and can cause lateral intrusion and down-coning of the water table surface in wells above these units (e.g., well 1), up-coning of saltwater in wells below these units (e.g., well 2), and poor flow rates in wells producing from within these units (e.g., well 3) 


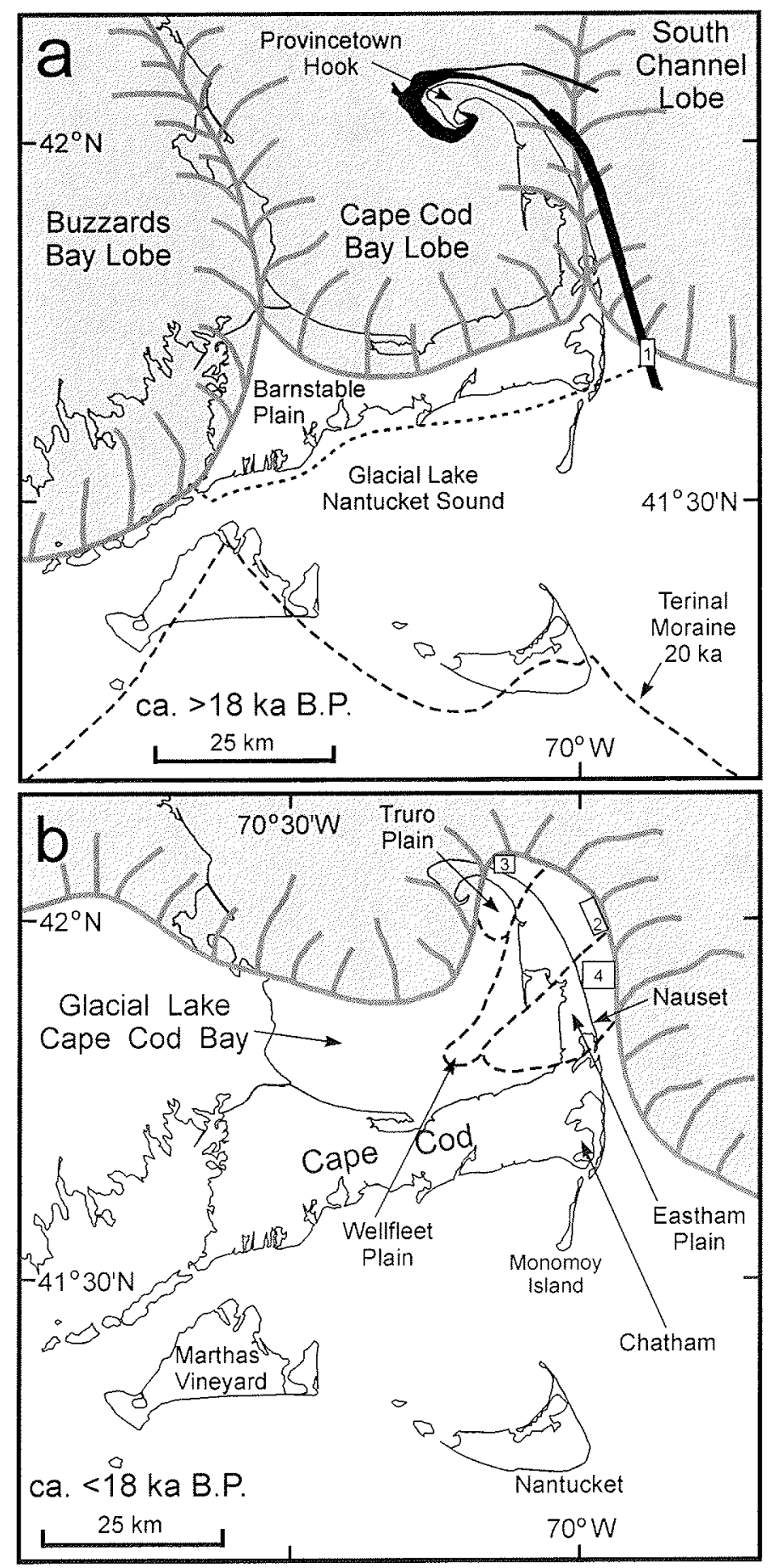




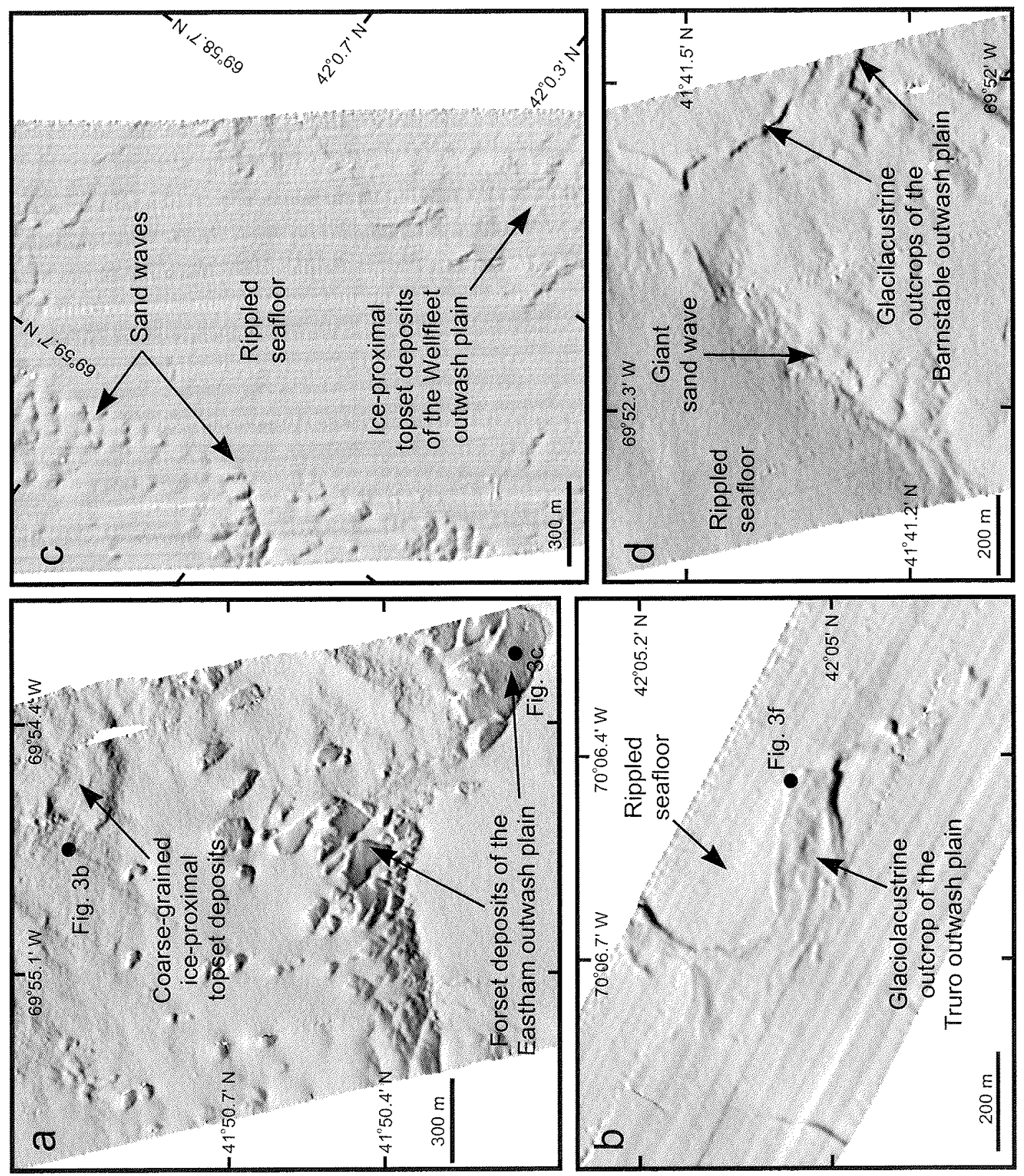



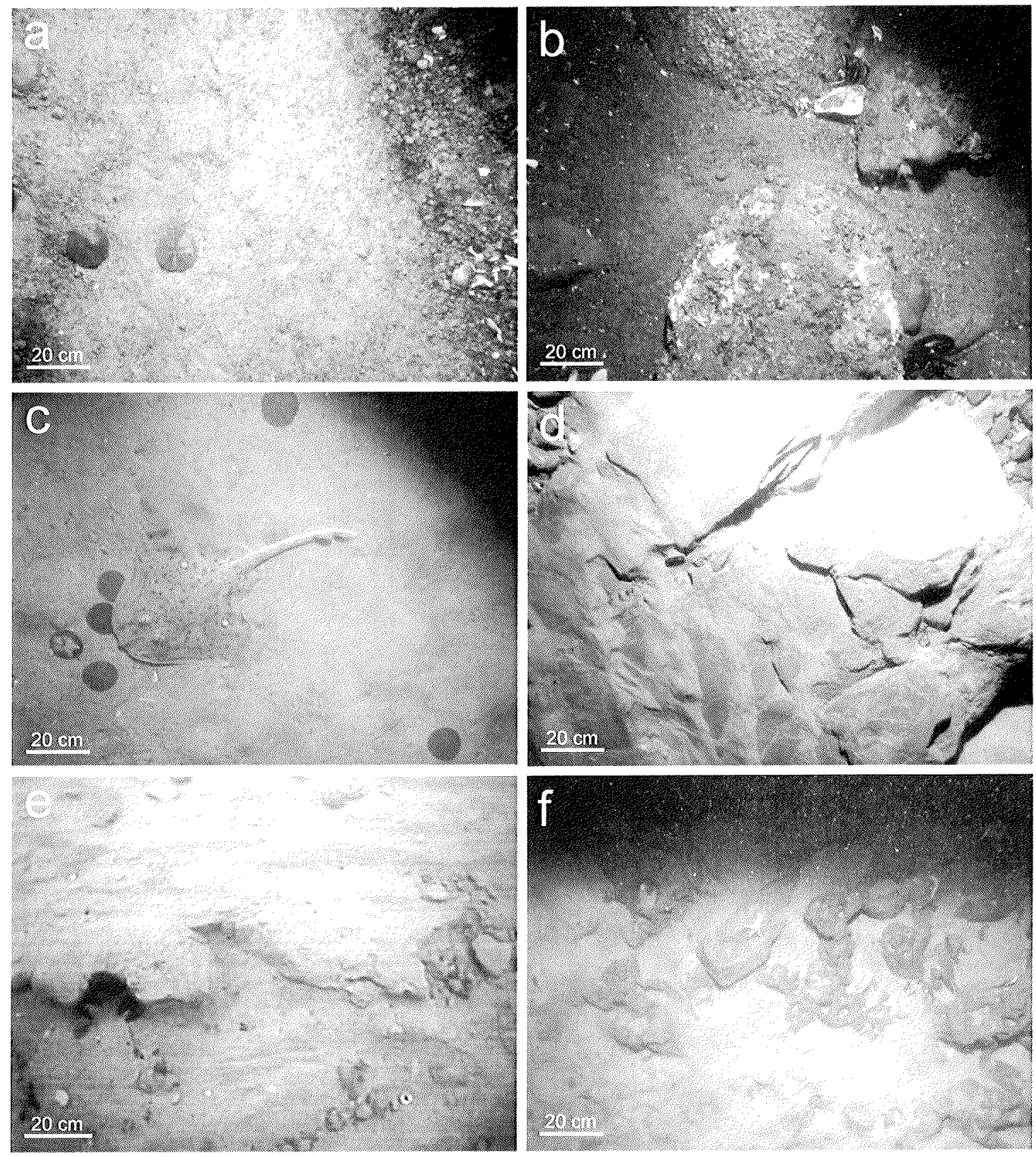


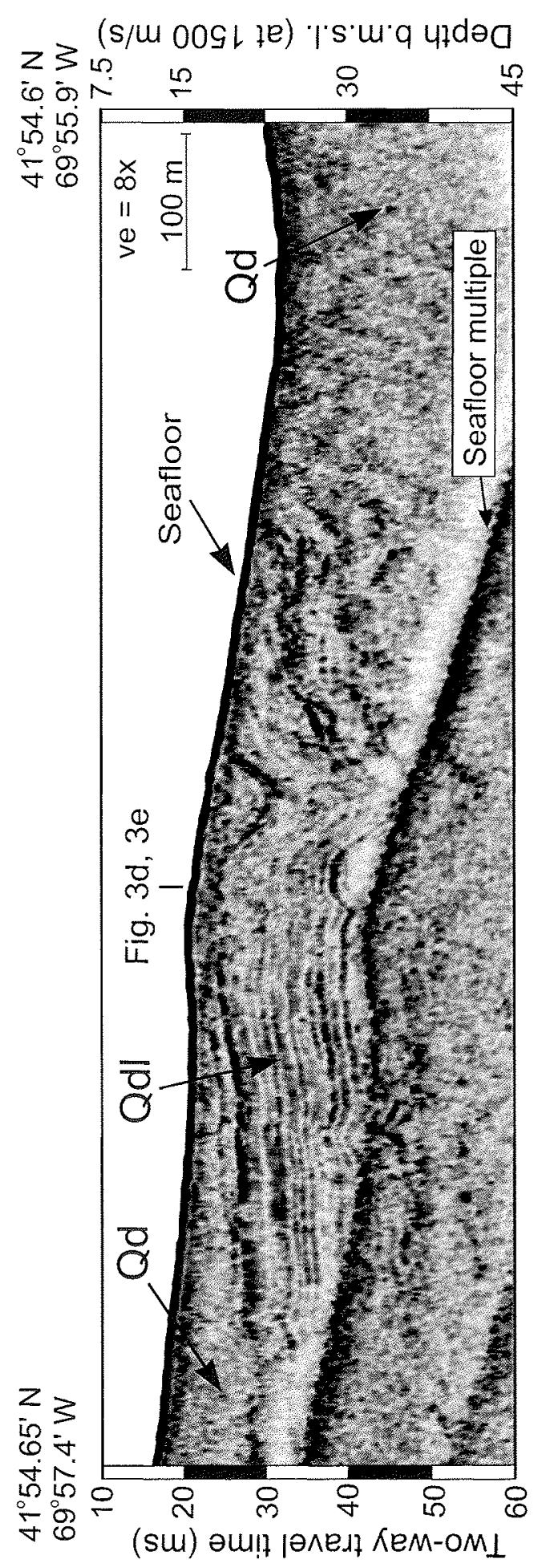




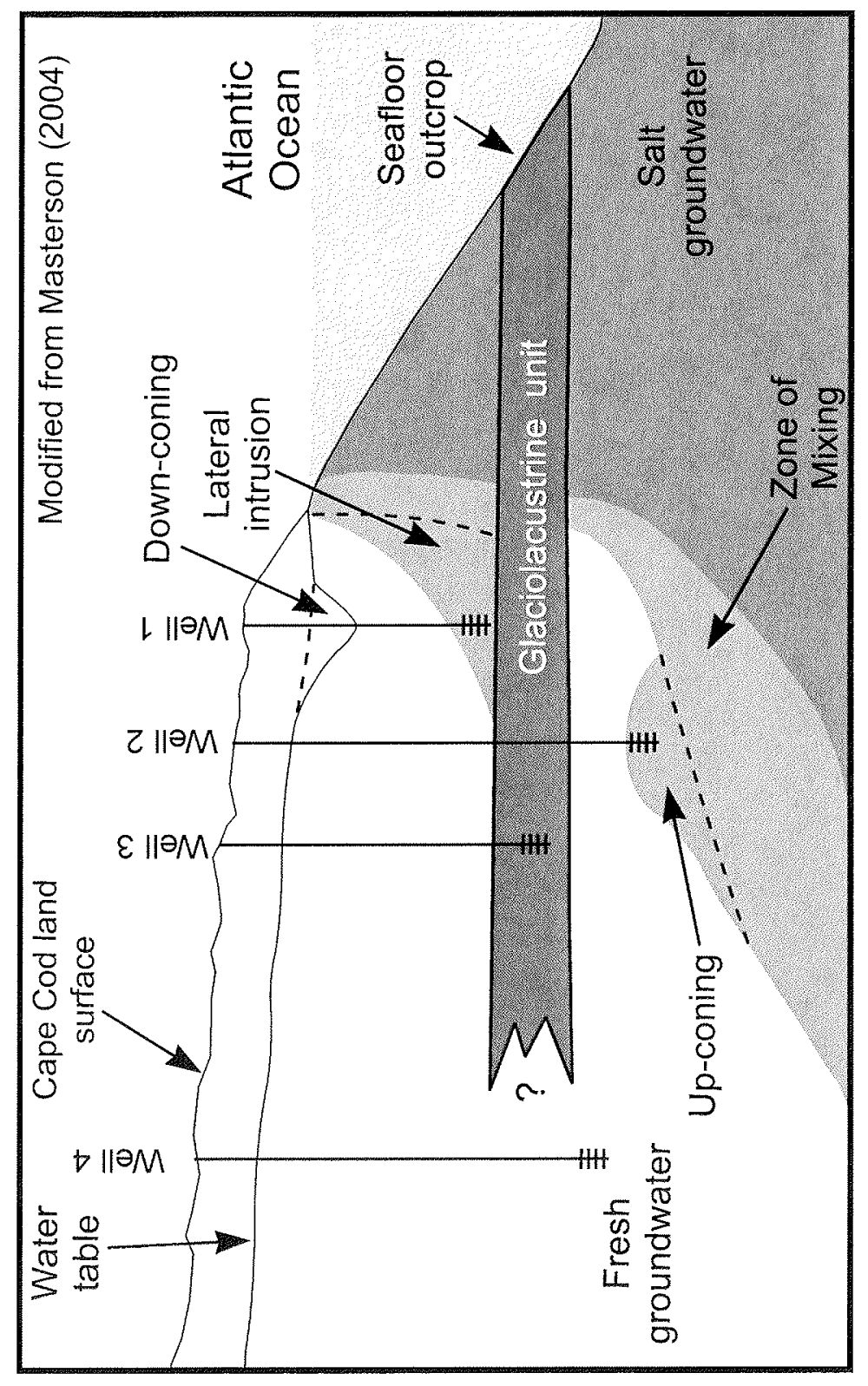

